Arch. histol. jap., Vol. 35, No. 4 (1973)

p. $289-299$

Department of Anatomy (Prof. Y. SANo), Kyoto Prefectural University of Medicine,

Kyoto, Japan

\title{
Quantitative Change of Dopamine in the Tuberohypophyseal Tract of the Rat under Some Experimental Conditions
}

\author{
Hideo Kanyama
}

Received February 6, 1973

Summary. Alterations in the content of primary catecholamines, especially dopamine, in the tractus tuberohypophyseus were studied in male albino rats under several experimental conditions by a histochemical fluorescence method for biogenic amines.

1. Dopamine in the tractus tuberohypophyseus completely disappeared after the administration of reserpine, while nialamide and L-dopa administration intensified dopamine specific green fluorescence in all varicose fibers of the infundibulum.

2. The content of dopamine in the tuberohypophyseal tract was altered during the following three experiments. Bilateral adrenalectomy induced an abrupt increase in the amount of dopamine. This increase in dopamine was suppressed by postoperative administrations of dexamethasone $(5 \mathrm{mg} / \mathrm{day}$ for 16 days). The amount of dopamine was also distinctly decreased in the case of the administration of dexamethasone $(5 \mathrm{mg} / \mathrm{day}$ for 16 days) without adrenalectomy.

3. Hypophysectomy resulted in a remarkable increase in the catecholamine content of the infundibulum.

4. Bilateral orchiectomy resulted in a slight increase in catecholamine in the external layer of the infundibulum.

5. The administration of histamine induced a marked decrease of monoamines in the median eminence. On the basis of these results the biological correlation between biogenic amines in the median eminence and regulating factors for the adenohypophysis was discussed.

By the use of histochemical fluorescence technique for the demonstration of catecholamines, CARLsson, FALCK and Hillarp (1962) observed a diffuse green specific fluorescence in the external layer of the median eminence in the hypophyseal stalk. It was later reported by FUXE (1964), ODAKE (1967) and others in various vertebrates that the Gomori-negative tuberohypophyseal fibers containing a large amount of biogenic amines, especially dopamine, terminate at the area surrounding the primary capillary plexus of the hypophyseal portal system and the external layer of the median eminence. Some investigators challenged to elucidate the biological role of the infundibular catecholamine with regard to the relation between biogenic amines and releasing hormones $(\mathrm{RH})$ for anterior pituitary cells. First AKMAyev and DonÁnTH (1965) fluorescent microscopically observed that catecholamines in the infundibulum underwent a remarkable quantitative change after adrenalectomy and hydrocortisone treatment, and they presumed the existence of a close correlation between the biogenic amines in the median eminence and $\mathrm{CRH}$ (corticotropin-releasing-hormone). However, Fuxe and HöKfELT (1967) rejected this opinion and reported that no change in the activity of the dopamine neurons could be demonstrated after adrenalectomy or cortisol treatment. They (1969), instead, maintained that the tuberoinfundibular 
dopamine neuron system appears to be specifically involved in the regulation of gonadotropin secretion from the anterior pituitary (inhibitor of the release of FSHRH and/or LHRH). Moreover, SMELIK (1969) stated that the presence of monoamines in the median eminence is not obligatory for the control of ACTH secretion, but dopamine may act as an inhibitory neurotransmitter for prolactin release. Thus, the results of the respective researches about the functional relation between dopamine and $\mathrm{RH}$ indicated no satisfactory agreement.

In this study, accordingly, the author tried to clarify the biological function of the tuberohypophyseal tract by persuing the relation of dopamine and $\mathrm{RH}$ by means of the extirpation of some endocrine glands (adrenal gland, pituitary gland and testis) and administration of various hormones and drugs which are known to influence the catecholamine metabolism.

\section{Materials and Methods}

Use was made of 85 male adult rats (200-250 g). The surgical operations such as bilateral adrenalectomy, hypophysectomy and bilateral orchiectomy and the pharmacological treatments performed in this study are shown in Table 1.

Table 1. Experimental conditions and case numbers

\begin{tabular}{|c|c|c|c|}
\hline Treatment & $\begin{array}{c}\text { Dose } \\
\text { (mg/kg body weight) }\end{array}$ & Time before killing & Number of rats \\
\hline Normal & & & 20 \\
\hline Reserpine i.p. & 5 & $\underset{24}{2} \mathrm{hrs}$ & $\begin{array}{l}5 \\
5\end{array}$ \\
\hline Bilateral adrenalectomy & & $\begin{array}{l}8 \text { days } \\
16\end{array}$ & $\begin{array}{l}10 \\
10\end{array}$ \\
\hline Hypophysectomy & & $\begin{array}{l}8 \text { days } \\
16 \\
24\end{array}$ & $\begin{array}{l}5 \\
5 \\
5\end{array}$ \\
\hline Castration ( $\hat{\delta})$ & & 14 days & 5 \\
\hline Dexamethasone i.p. & 5 per day; total: 80 & 16 days & 5 \\
\hline $\begin{array}{l}\text { Dexamethasone i.p. after bilateral } \\
\text { adrenalectomy }\end{array}$ & 5 per day; total: 80 & 16 days & 5 \\
\hline Histamine i.p. & 100 & $1 \mathrm{hr}$ & 5 \\
\hline
\end{tabular}

All the operations were performed under light ether anesthesia. The pituitary gland was extirpated by negative pressure suction with an injection syringe from the temporal area behind the ear. The animals, between the operation and sacrifice, were maintained at a constant temperature $\left(22^{\circ} \mathrm{C}\right)$ in an isolated room and given $1 \%$ saline to drink and fed on a diet of commercial rat chow. The brain tissue was rapidly frozen by direct immersion in an isopentane dry ice mixture and were freeze-dried in vacuo for 7 days at a temperature of $-35^{\circ} \mathrm{C}$ after being kept at $-20^{\circ} \mathrm{C}$ for $24 \mathrm{hrs}$, at $35^{\circ} \mathrm{C}$ for $12 \mathrm{hrs}$ and at $60^{\circ} \mathrm{C} 1 \mathrm{hr}$. They were then transferred to a glass vessel containing granular paraformaldehyde, which had been stored for 7 days in an 
atmosphere of $80 \%$ relative humidity. The vessel was then placed in an oven at $80^{\circ} \mathrm{C}$ for $1 \mathrm{hr}$. The specimens were infiltrated with soft paraffin in vacuo and embedded, sectioned (10 $\mu$ thick), and mounted in an entellan xylen mixture.

Fluorescence microscopy was performed with an Ultraphot II (Zeiss) with a HBO 200 high pressure mercury lamp, a BG 12 excitation filter, a dark-field condenser for immersion oil, and a Zeiss 50 barrier filter.

After microphotography with the fluorescence microscope the sections were also examined with a phase contrast microscope. Further, a large number of these sections were stained with hematoxylin-eosin or aldehyde-thionin Masson's trichrome for identification and localization of the fluorescent materials and for examination of the quantitative changes of the Gomori-positive neurosecretory substance.

\section{Results}

It is well kown that the infundibulum contains two different tracts, namely the non-fluorescent Gomori-positive neurosecretory tract and fluorescent Gomori-negative tuberohypophyseal tract. The former arises from the supraoptic and paraventricular nuclei and terminates mainly through the internal layer of the hypophyseal stalk at the perivascular area of the neural lobe. The latter arises from the so-called hypophysiotrophic area such as the arcuate and anterior periventricular nuclei. These fibers extend to the external layer of the median eminence through the internal layer and terminate at the boundary surface of the tuberal lobe or the perivascular area of the primary capillary loops of the hypophyseal portal system. The tuberohypophyseal tract consists of the dopamine containing neurons, showing a yellowish green color (max. excitation $410 \mathrm{~m} \mu / \mathrm{max}$. emission $480 \mathrm{~m} \mu$ ) by the fluorescence histochemical method for the demonstration of catecholamine. In the infundibulum the processes of the monoaminergic neurons showing as chains of fluorescent varicosities run among the non-fluorescent neurosecretory fibers and enter the external layer after making a right angle turn in the internal layer. Part of the fibers penetrate into the internal layer and then terminates at the wall of the capillary loops of the portal system. When the freeze drying method is carried out precisely and the diffusion of biogenic amines has not happened, the respective fluorescent nerve fibers arranged perpendicularly to the surface of the external layer are clearly distinguished and form a layer that may be called the "zona palisadica." Generally, in case of the untreated control rats, the contrast between the strongly fluorescent external layer and the relatively dark internal layer containing scattered fluorescent varicose fibers also may be clearly recognized (Fig. 1 ).

Under the experimental conditions the quantitative change of the fluorescent substance in the median eminence may be determined by considering all the factors such as the increase or decrease of the thickness of the fluorescent zone in the external layer, the quantity and size of the fluorescent varicosities in the internal layer and the intensity of the fluorescence of the perikarya of the nerve cells in the arcuate nucleus.

Reserpine treatment: The fluorescence of the terminals in the external layer had almost completely disappeared $2 \mathrm{hrs}$ after the administration of reserpine $(5 \mathrm{mg} / \mathrm{kg})$. But a weak fluorescence remained in the vicinity of the capillary loops of the hypophyseal portal system and also in the thick fibers with large varicosities 


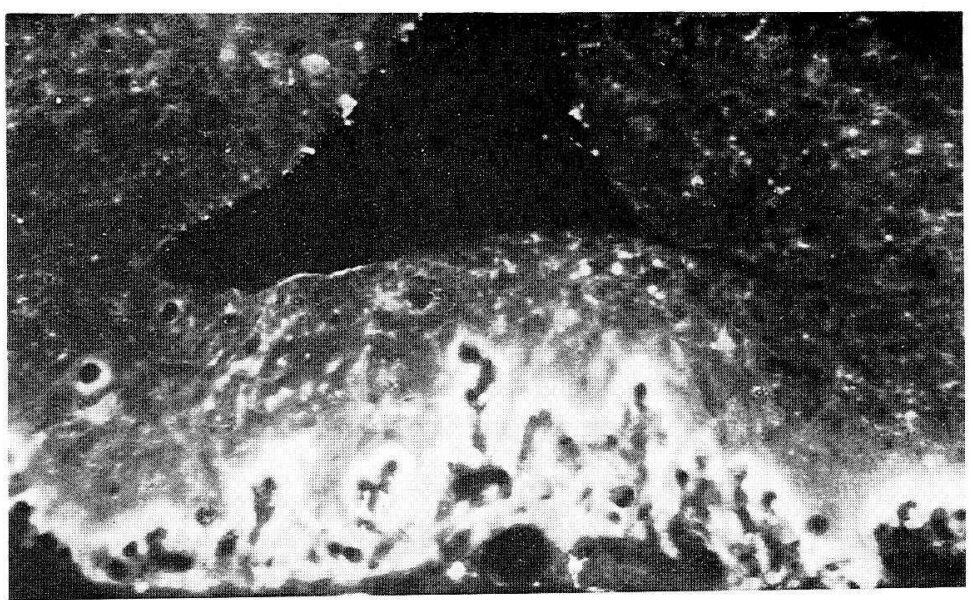

Fig. 1. Monoamine fluorescence in the infundibulum of a normal rat. $\times 210$, also in all other figures.

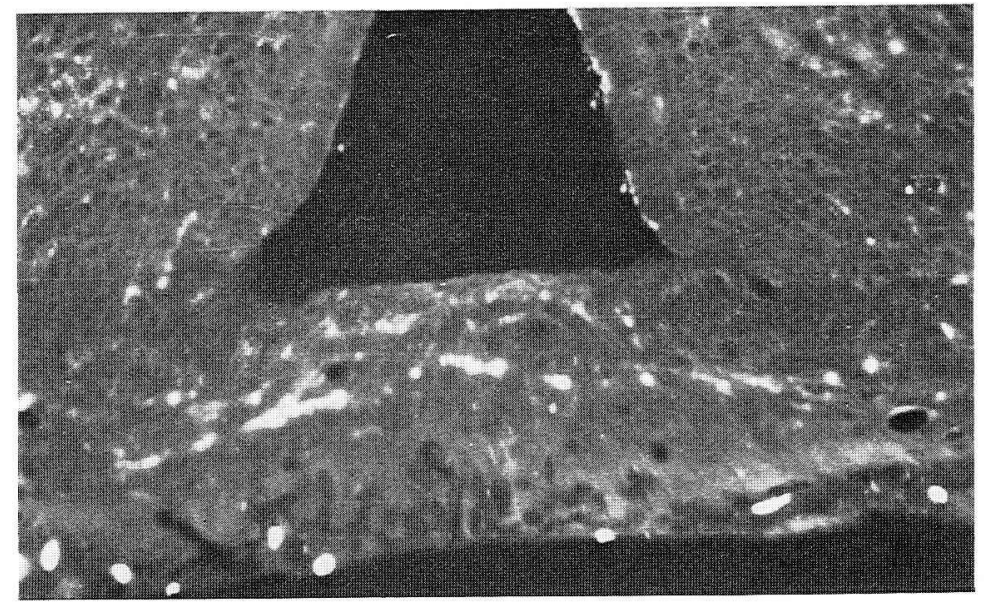

Fig. 2. Median eminence 24 hrs after reserpine administration. In both external and internal layers the fluorescence is completely disappeared.

in the internal layer. Nerve cell bodies containing fluorescent substance were seldom found in the arcuate nucleus. Such a tendency for the fluorescence to disappear of developed as time passed and $24 \mathrm{hrs}$ later the catecholamine fluorescence was totally absent in the hypothalamohypophyseal system (Fig. 2).

Nialamide treatment: An increase of the fluorescence was recognized 4 hrs after administration of nialamide $(500 \mathrm{mg} / \mathrm{kg})$. The particularly noticeable results were that the fluorescence of the perikarya of the arcuate nucleus had become much clearer and the DA containing neurons were also increased in number.

Adrenalectomy: The fluorescence in the external layer 8 days after bilateral adrenalectomy was already remarkably increased and its width had become thicker, while the number of varicose fibers increased (Fig. 3). In the adrenalectomized rats 


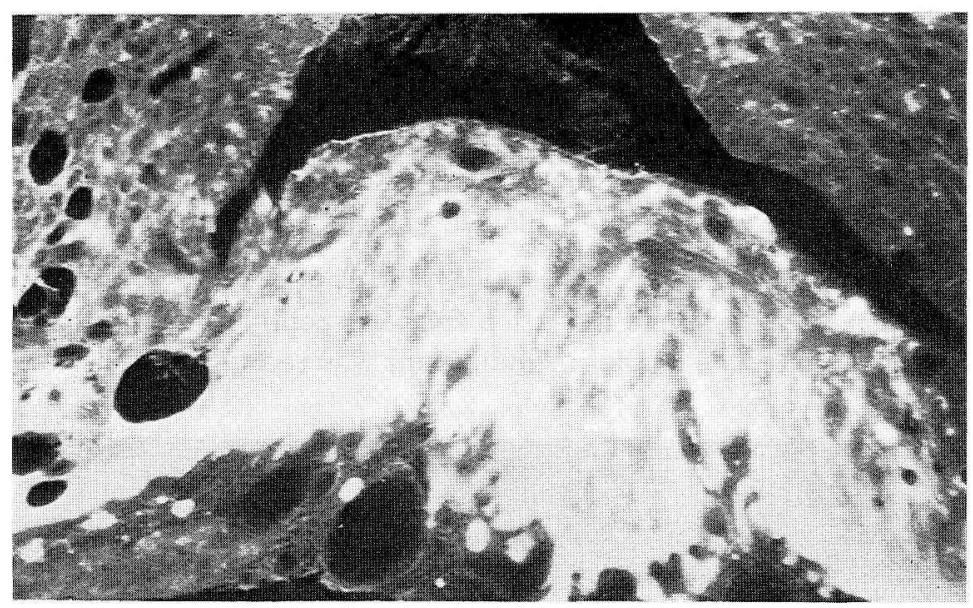

Fig. 3. Median eminence after bilateral adrenalectomy (8 days after operation). An intensified fluorescence is seen especially in the external layer.

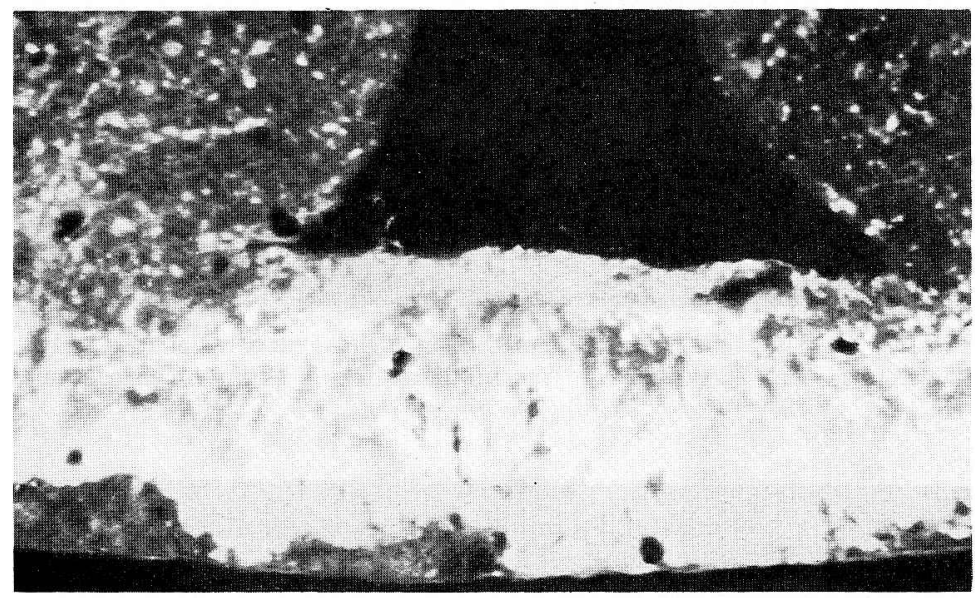

Fig. 4. Median eminence after bilateral adrenalectomy (14 days after operation). The fluorescence in both external and internal layers is markedly enhanced.

on the 14th day after the operation, the tendency of the fluorescence to increase became indistinct due to the increase of the thickness of the fluorescent layers surrounding the sinusoidal loop capillary and to the conspicuous reinforcement of the tuberohypophyseal fibers passing through the internal layer (Fig. 4). As the function of catecholamine production in the nerve cell body is moreover activated, the floor of the third ventricle including the hypophysiotrophic area showed a strong fluorescence.

Dexamethasone treatment: In the cases where $5 \mathrm{mg} /$ day of dexamethasone (total dose $80 \mathrm{mg}$ ) was administrated for 16 days immediately after bilateral adrenalectomy, the fluorescence in the infundibulum was slightly more increased in grade than that 
of the control animals (Fig. 5). There were remarkable differences between these cases and the cases of adrenalectomy alone. In these cases the distinction between both the external layers was very clear.

In the dexamethasone-treated animals ( $5 \mathrm{mg} /$ day, total dose $80 \mathrm{mg}$ ) without adrenalectomy, the fluorescence in the external layer was weakened and small discontinuous varicosities were seen dispersed in the internal layer of the median eminence (Fig. 6).

Hypophysectomy: After the extirpation fo the hypophysis a quantitative change of the fluorescence materials of the infundibulum was recognized for 4 weeks. The

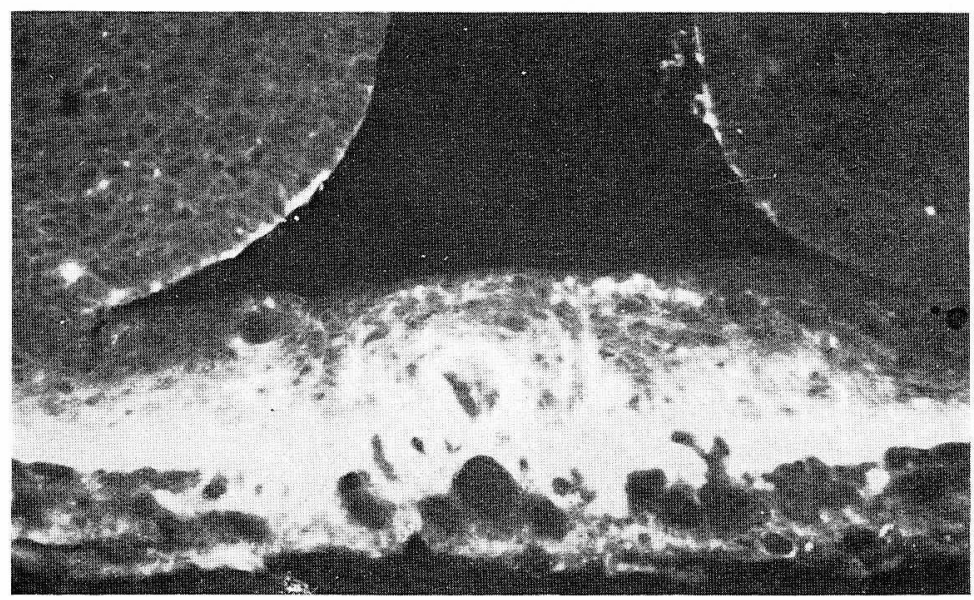

Fig. 5. Median eminence of dexamethasone treated rat after bilateral adrenalectomy. The fluorescence in the infundibulum is slightly more intense than in the control rat.

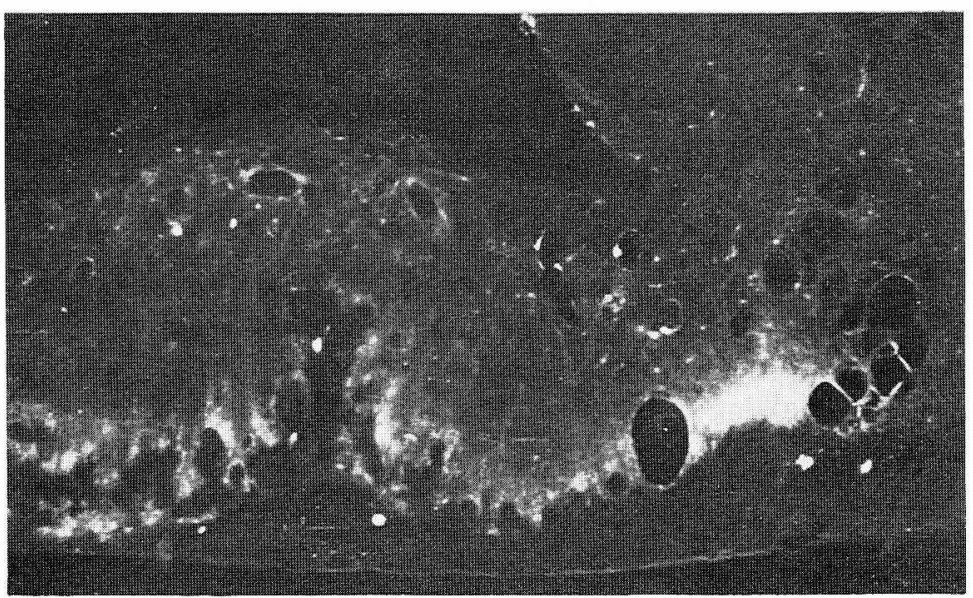

Fig. 6. Median eminence after dexamethasone administration alone. Only a thin fluorescent layer is seen on the outer surface of the infundibulum. 
fluorescence in the median eminence already showed a cosiderable increase in quantity in the first week (Fig. 7). By total hypophysectomy the nonfluorescent neurosecretory fibers, which were segregated from the neural lobe, began to be reorganized and they extended toward the external layer from the internal layer. A definite distinction between the two layers became difficult to make. On the 16th day after the operation, the reorganization of the nonfluorescent neurosecretory fibers had already occurred: they penetrated into the external layer and mingled with the dopaminergic tuberohypophyseal fibers. Simultaneously, at this time, a disorder began to occur also in the arrangement of the fluorescent fibers. A part of the fluorescent fibers evidently penetrated into the third ventricle. The increase in quantity of the fluorescence was less conspicuous in the case of hypophysectomy than in bilateral adrenalectomy.

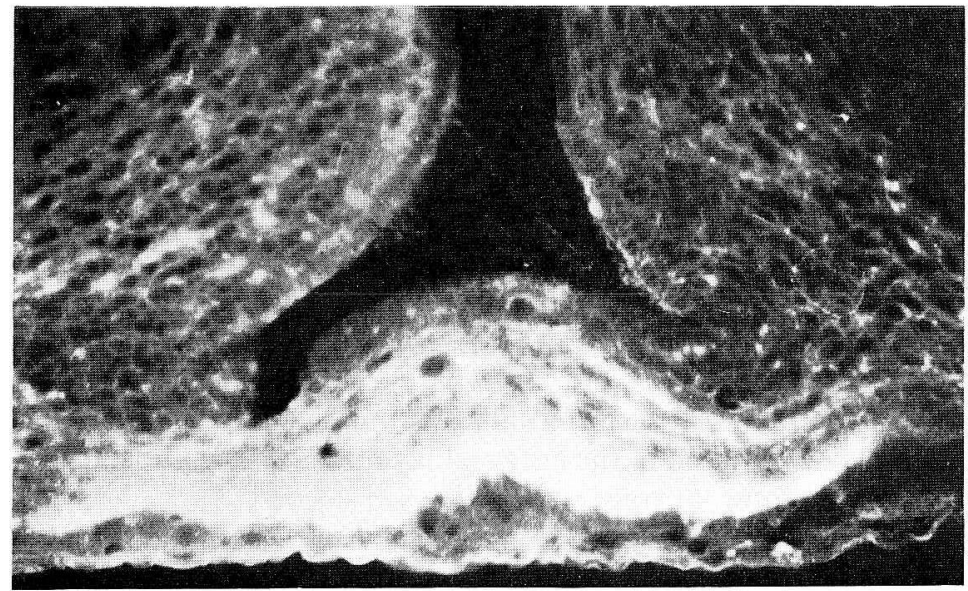

Fig. 7. Median eminence after hypophysectomy. The fluorescence is considerably increased as compared with the control.

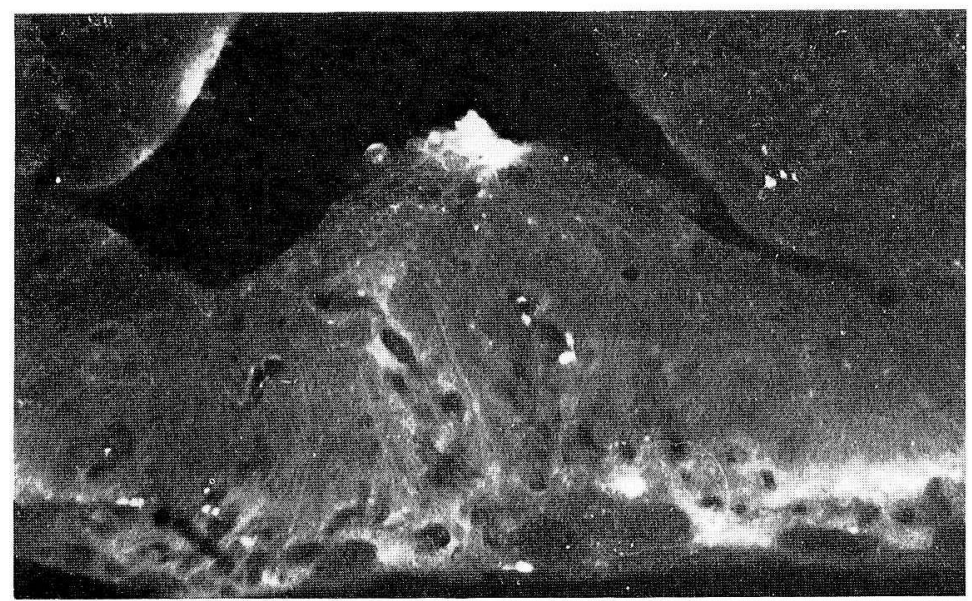

Fig. 8. Median eminence after histamine administration. Fluorescence occurs only on the summit of the infundibular section. 
Histamine treatment: At $30 \mathrm{~min}$ after administration of histamine $(100 \mathrm{mg} / \mathrm{kg})$ the fluorescence in the infundibulum was remarkably decreased in comparison with that of the control rat. A few linear, fluorescent structures were observed on the outermost surface of the external layer of the median eminence (Fig. 8).

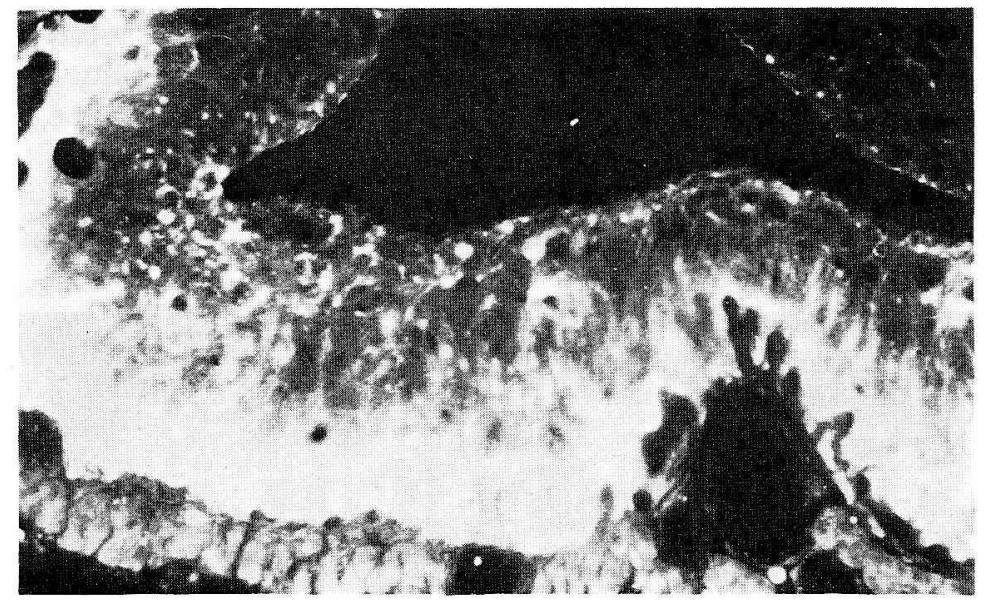

Fig. 9. Median eminence of a castrated rat. A remarkable accumulation of the fluorescent material in the external layer is shown.

Castration: On the 16th day after bilateral orchiectomy, an accumulation of the fluorescent materials was seen in the external layer and the fluorescent varicose fibers running through the internal layer were increased (Fig. 9). However, the distinction of the external and internal layers remained relatively clear.

\section{Discussion}

More than ten years have passed since the existence of hypothalamic releasing: hormones specific for the secretory activities of the adenohypophysis seemed to be established. Nevertheless, the chemical structure of RHs, except for TRH and LHRH, is still unexplained today and also morphological study on the cellular origin of RHs has made no further progress.

However, since FuxE (1964) revealed that the tuberohypophyseal tract arising from the so-called hypophysiotrophic area and terminating at the wall of the capillary loops in the median eminence contains a large amount of catecholamine, the investigation on the relations between the synaptic vesicles, biogenic amines and $\mathrm{RH}$ has become one of the most important neuroendocrinological themes.

In order to elucidate these relationships, it seems worthwhile to examine the changes of the fluorescence of the tuberohypophyseal amines under some experimental conditions which have been known to cause increase or decrease of RH content.

On the basis of experiments with $\alpha$-methyl-metatyrosine and desmipramine of the rat and mouse, CARlsson, FAlck and Hillarp (1962), CARlsson and Lindquist (1962), Fuxe (1964), Fuxe, Hamberger and Malmfors (1966) suggested that the majority of the fluorescent nerve fibers in the median eminence contain dopamine. 
The opinion that the fine nerve terminals in the external layer are dopaminergic has been accepted by many investigators. On the other hand, BJöRKLUND, FALCK and Rosengren (1967), BuöRKLund and FALCK (1969), Björklund, et al. (1970) found that the diencephalohypophyseal noradrenergic fibers in addition to the arcuatohypophyseal dopamine fibers have their terminals in the median eminence. Moreover, they suggested the exsistence of a third neuron system, probably containing an indole derivative.

However, it is now very difficult to endorse the relation between each $\mathrm{RH}$ and concurrent biogenic amine with a distinction between three different catecholaminergic neuron systems.

The facts that the activity of ACTH cells in the adenohypophysis is stimulated after adrenalectomy and that the ACTH content in the pituitary gland and blood decreases after the administration of corticoid were established by the experiments on the incorporation of ${ }^{14} \mathrm{C}$-labeled amino acid into ACTH. Wool, ScharfF and Moges (1961) and VeRnicos-Daniellis (1965) reported that the CRH activity in the median eminence was strengthened by adrenalectomy and it was suppressed even after stress caused by cortisone administration. Akmayev and DonÁth (1965) supported this opinion from the histological standpoint: they found that the catecholamine fluorescence in the median eminence gradually increased for 16 days after bilateral adrenalectomy and this increase was suppressed by an administration of hydrocortisone. In our study, it was also possible to clarify that the adrenalectomy and the dexamethasone treatment in high doses caused a remarkable quantitative change of the fluorescent substance in the tuberohypophyseal tract. Akmayev and Donáth mentioned that the infundidular fluorescence gradually decreased more than 16 days after the operation, but in our study no decrease was shown until 4 weeks later.

Negative results on the correlation between $\mathrm{CRH}$ and catecholamine have been reported by some investigators: FuxE and HöKFELT (1967) stated that no significant quantitative change occurred in the tuberoinfundibular dopamine fluorescence after administration of large doses of glucocorticoid.

On the basis of the experiment of reserpine implantation in the hypothalamus, SMELIK (1969) also reported, that dopamine was not essential for the regulation of ACTH. From the results of these studies, it was certain that the tuberohypophyseal catecholamines were closely related to the production and/or release of $\mathrm{CRH}$. However, the question as to whether the administration of dexamethasone was acting on the corticotrophs of the anterior pituitary through $\mathrm{CRH}$ or directly may not be settled by this study alone.

Concerning hypophysectomy, quantitative changes of the infundibular fluorescence were seen in our research for a 28 day period after the operation. Our study, similar to ODAKE's report (1967), indicated an increase of catecholamines in the median eminence. However, an interpretation of the results after hypophysectomy is not easy because many factors besides the simple hormonal change, e.g., destruction of the primary capillary loops of the hypophyseal portal system and transneuronal degeneration of the hypothalamohypophyseal tract, intervene in the functional impediment of the hypothalamohypophyseal system. Accordingly, it is quite important to consider that hypophysectomy did not produce a pure defective condition of pituitary hormones. The total hypophysectomy causes a severe damage to the structure 
of the hypophyseal stalk and, in consequence, there may follow a disorder in the distinct arrangement of the internal and external layers. Thus, the fluorescent tuberohypophyseal tract and nonfluorescent supraopticohypophyseal tract mingle with each other, while the distribution of the primary capillary loops undergoes a strong change. Accordingly, fluorescent zone of the external layer would be dispersed day by day after the operation and the fluorescent fibers would be scattered in the internal layer and the ependymal layer. As a result, it would become difficult to show the increase in the fluorescent quantity by comparing it with other experimental examples.

Fuxe (1964), Fuxe, Hökfelt and Nilsson (1969a, b) emphasize that the tuberoinfundibular dopamine neurons participate in gonadotropin regulation and that the dopamine released acts locally in the median eminence to block the synthesis and/or inhibitory factors involved in the regulation of gonadotropin secretion, possibly mainly the LHRH. They reported, furthermore, that castration alone did not cause any definite change in the turnover in the dopamine nerve terminals of the male rat, though in the female it blocked the variations in turnover observed during the ovarian cycle. The present study, on the contrary, clearly demonstrated that the dopamine fluorescence in the median eminence was increased after castration of the male rat. This conspicuous difference in the results after orchiectomy between the study of FuxE and his associates and ours remains unexplained.

\section{ラットの隆起下垂体路におけるドーパミンの量的変化について}

$$
\text { 完山秀 雄 }
$$

雄のラット80匹を用い，隆起下垂体路に含まれるアミン，主としてドーパミンの実験 条件下における量的変化を観察した。

1. 隆起下垂体路に含まれるドーパミンはレセルピンの投与によって消失する.

2. 両側の副腎摘出後, 隆起下垂体路のドーパミンは急激に増加する. 手術後 dexamethasone を連日投与して行くと，その量の増加がおさえられる。 また手術定行わず dexamethasone のみを与えると，対照例以下に減少する.

3. 下垂体摘出によって 漏斗のドーパミンは増加する.

4. 精巣摘出によっても ドーパミンはある程度 増加する.

5. ヒスタミンの投与は 漏斗のアミンを減少させる.

以上の結果，ドーパミンは隆起下垂体路における放出因子の活性変動パターンに密接 に関係していることが明らかになった。

\section{References}

Akmayev, I. G. und T. Donáth: Die Katecholamine der Zona palisadica der Eminentis mediana des Hypothalamus bei Adrenalektomie, Hydrocortisonverabreichung und Stress. Z. mikrosk.-anat. Forsch. 74: 83-91 (1965). 
Björklund, A. and B. Falck: Pituitary monoamines of the cat with special reference to the presence of an unidentified monoamine-like substance in the adenohypophysis. Z. Zellforsch. 93: 254264 (1969).

Björklund, A., B. Falck, F. Homek, C. Owen and K. A. West: Identification and terminal distribution of the tubero-hypophyseal monoamine fiber systems in the rat by means of stereotaxic and microspectrofluorimetric techniques. Brain Res. 17: 1-23 (1968).

Björklund, A., B. Falck and E. Rosengren: Monoamines in the pituitary gland of the pig. Life Sci. 6: 2103-2110 (1967).

Carlsson, A., B. Falck and N.-A. Hillarp: Cellular localization of brain monoamines. Acta physiol. scand. 56 (Suppl. 196): 1-28 (1962).

Carlsson, A. and M. Lindqvist: In vivo decarboxylation of $\alpha$-methyl dopa and $\alpha$-methyl metatyrosine. Acta physiol. scand. 54: 87-94 (1962).

Fuxe, K.: Cellular localization of monoamines in the median eminence and the infundibular stem of some mammals. Z. Zellforsch. 61: 710-724 (1964).

Fuxe, K., B. Hamberger and T. Malmfors: Inhibition of amine uptake in tubero-infundibular dopamine neurons and in catecholamine cell bodies of the area postrema. J. Pharmacol. 18: 543-544 (1966).

Fuxe, K. and T. Hökfelt: The influence of central catecholamine neurons on the hormone secretion from the anterior and posterior pituitary. In: (ed. by) F. Stutinsky: Proc. 4th Int. Symp. of Neurosecretion (Strassburg, 1966). Berlin-Heidelberg-New York, Springer-Verlag, 1967. (p. 165-177).

: Catecholamines in the hypothalamus and the pituitary gland. In: (ed. by) W. F. Ganong and L. Martini: Frontiers in neuroendocrinology, 1969. London-Tronto, Oxford University Press, 1969. (p. 47-96).

Fuxe, K., T. Hökfelt and $\mathbf{O}$. Nilsson: Castration, sex hormones, and tubero-infundibular dopamine neuron. Neuroendocrinology 5: 107-120 (1969a).

- Factors involved in the control of the activity of the tubero-infundibular dopamine neurons during pregnancy and lactation. Neuroendocrinology 5: 257-270 (1969b).

Odake, G.: Fluorescence microscopy of the catecholamine-containing neurons of the hypothalamohypophyseal system. Z. Zellforsch. 82: 46-64 (1967).

Smelik, P. G.: Role of hypothalamic monoamine in the control of pituitary secretions. J. neuroviscer. Relat. (Suppl. IX): 277-282 (1969).

Vernikos-Danellis, J.: Effect of stress, adrenalectomy, hydrocortison on the corticotropin-releasing activity of rat median eminence. Endocrinology 76: 122-126 (1965).

Wool, R. A. G., R. Scharff and N. Moges: In vitro synthesis of $\mathrm{C}^{14}$-corticotropin by isolated rat anterior pituitary effect of adrenalectomy. Amer. J. Physiol. 201: 547-550 (1961).

\author{
完山秀雄 \\ 产602 京都市上京区河原町広小路 \\ 京都府立医科大学 \\ 第一解剖学教室
}

Dr. Hideo KanYama

Department of Anatomy

Kyoto Prefectural University of Medicine

Kyoto, 602 Japan 